\title{
PELAYANAN KONSELING KRISTEN KEPADA PASANGAN SUAMI ISTERI DALAM MENYELESAIKAN KONFLIK KELUARGA
}

\author{
Agus Suryo Jarot Yudhono
}

\section{PENDAHULUAN}

Seiring dengan perkembangan zaman, hidup manusia semakin kompleks dan tantangan semakin beragam. Manusia banyak diperhadapkan oleh beragam problematika yang melilit kehidupan. Ketakutan, keputusasaan, kesepian, kebimbangan, kebingungan, kemarahan, kebencian terpendam, perasaan-perasaan ketidakberdayaan menyelimuti jiwa. Problema hidup tidak saja dialami secara individu, namun juga terjadi pada pasangan suami isteri. Pada pasangan suami isteri problem yang dihadapi lebih kompleks sebab pasangan suami isteri merupakan dua individu yang memiliki banyak perbedaan mulai dari perbedaan pandangan, latar belakang kebiasaan yang berbeda dan sebagainya. Meskipun pasangan sumai isteri memiliki perbedaan pandangan, namun hal itu merupakan karya Tuhan untuk mempersatukan keduanya demi keberlangsungan kehidupan di bumi (Kej. 1: 27, 28; 2: 18, 21, 22).

Konflik adalah bagian alami dari kehidupan. Banyak orang yang beranggapan bahwa konflik adalah suatu kontroversi terbuka. Namun, definisi konflik yang lebih benar ialah hilangnya kedamaian - yang hanya bisa didapatkan sepenuhnya dari Allah ${ }^{1}$. Ketika manusia saling berinteraksi, perbedaan pendapat atau tujuan bisa saja terjadi. Pada umumnya, kita bisa mengatasi perbedaan-perbedaan kecil. Namun, ketika konflik yang besar timbul, banyak orang yang tidak tahu harus berbuat apa. Keluarga yang sedang menghadapi konflik hendaknya bisa mendapatkan pelayanan konseling secara khusus, sehingga keluarga tersebut menemukan solusi yang tepat dan tahu harus berbuat apa dalam menyelesaikan konflik keluarga.

Fakta yang terjadi, masih banyak dijumpai pasangan suami isteri ketika menyelesaikan konflik keluarga tidak diselesaikan dengan baik dan tidak alkitabiah. Penyelesaian konflik keluarga tidak dilakukan dengan cara-cara yang benar sehingga dampaknya kepada perpecahan keluarga atau disharmonisasi keluarga. Penyebab Konflik keluarga yang terjadi sangat kompleks, mulai dari masalah mendidik dan mengurus anak, ekonomi,

1 Robert Banks \& R. Paul Stevens, The Complete Book of Everyday Christianity, (Bandung: Kalam Hidup, 2012), 344 
perbedaan pendapat antara pasangan, sampai masalah perselingkuhan, dan sebagainya. Dalam proses penyelesaian konflik keluarga pasangan suami isteri lebih mengedepankan kebenaran masing-masing pendapatnya tanpa melibatkan orang ketiga untuk memediasi konflik yang terjadi. Sehingga yang terjadi adalah masalah tidak terselesaikan dengan tuntas akibatnya jika konflik yang sama muncul kembali maka bagaikan bom waktu yang meledak dengan keras. Penyelesaiannya tidak sampai ke akar rumputnya sehingga hanya menimbun dan menimbun masalah, yang pada akhirnya menjadi sebuah gunung persolan atau masalah keluarga tanpa akhir. Dampak yang lebih besar jika konflik keluarga antara pasangan suami isteri tidak terselesaikan maka perceraian menjadi solusi terakhir.

Keluarga yang sedang menghadapi konflik hendaknya bisa mendapatkan pelayanan konseling secara khusus, sehingga keluarga tersebut mampumenemukan solusi yang tepat dalam menyelesaikan konflik. Pelayanan konseling kristen, klien dibimbing dan dibantu untuk dapatmelihat aspek-aspek kehidupannya secara kristen dan lebih luas, dalam hubungan dan tanggung jawabnya kepada Tuhan ${ }^{2}$. Konselor sebagai mediator bagi keluarga yang sedangdalam menyelesaikan konflikbisa memberikan pendidikan, pembinaan dan pengawasan terhadap keluarga.

\section{Hakikat Pasangan Suami Isteri}

Allah menciptakan dan membentuk dua insani yang disebut laki-laki dan perempuan (Kejadian 1:27). Manusia pertama disebut Adam yang dipertemukan dengan Hawa oleh Tuhan agar menjadi pasangan suami isteri, dan diberikan sistem yang kemudian disebut pernikahan. ${ }^{3}$ Keduanya diciptakan oleh Allah untuk saling melengkapi perbedaan diantara mereka dalam satu ikatan hubungan yang intim. Allah menghendaki adanya keintiman antara suami dan isteri, sehingga seluruh kebutuhan fisik dan emosional mereka dapat dipenuhi dalam hubungan itu. ${ }^{4}$ Hubungan tersebut terbungkus di dalam sebuah pernikahan. Jika mereka telah dipersatukan dalam pernikahan maka seorang laki-laki akan disebut suami dari isterinya, dan seorang perempuan akan disebut isteri dari suaminya. Keduanya menjadi sepasang suami isteri yag terikat dalam pernikahan.

Pembahasan yang berkaitan dengan pasangan suami isteri, tidak dapat dipisahkan dari awal permulaan Allah menciptakan manusia dan tujuannya. Di mulai dari Kejadian 1:26, "Berfirmanlah Allah: "Baiklah kita menjadikan manusia menurut gambar dan rupa Kita, supaya mereka berkuasa atas ikanikan di laut dan burung-burung di udara dan atas ternak dan atas segala

2 Yakub B. Susabda, Pelayanan Konseling Melalui Telepon, (Yogyakarta: ANDI, 2007), 102

3 Ki Bagus Heruyono, Pernikahan Awal Perjalanan Panjang (Blitar: Tiberias Blitar Publishing, 2011), 2

4 Billy Joe Daugherty, Pernikahan Yang Kokoh (Jakarta:Metanoia, 2001), 11 
binatang melata yang merayap di bumi”. Penciptaan manusia merupakan inisiatif Allah untuk menciptakan makhluk yang disebut manusia. Selanjutnya di dalam Kejadian 1:27, "Maka Allah menciptakan manusia itu menurut gambat-Nya, menurut gambar Allah diciptakan-Nya dia; laki-laki dan perempuan diciptakan-Nya mereka".Larry Christenson dalam bukunya, Keluarga Kristen menuliskan tentang penciptaan manusia oleh Allah, sebagai berikut:

Allah menjadikan manusia dalam bentuk pria dan wanita sebagai suatu bagian dasar dari ciptaanNya; hal ini merupakan sebagain pernyataan dari batin Allah. Pada saat Ia menciptakan manusia menurut gambarNya sendiri, Ia tidak hanya menciptakan laki-laki. Ada sesuatu yang kurang. Itulah sebabnya Ia berfirman: "Aku akan menjadikan penolong baginya, yang sepadan dengan dia" (Kejadian 2:18). Lalu Ia menciptakan wanita. Kini IA memperoleh manusia yang lengkap. Pria dan wanita hidup bersama dalam pernikahan, mewujudkan kesempurnaan Allah dalam ciptaanNya. ${ }^{5}$

Di jelaskan bahwa manusia bukan saja dalam bentuk laki-laki, namun manusia juga dalam bentuk perempuan. Allah menciptakan laki-laki dan perempuan untuk hidup bersama dan benar-benar memenuhi bumi dengan keturunan-keturunan ilahi. Ia menciptakan laki-laki dan perempuan dengan cara tertentu supaya mereka dapat menghasilkan keturunannya sendiri. ${ }^{6}$ Sehingga keduanya menjadi suatu ciptaan Allah yang sempurna dan saling melengkapi, sebab Allah berfirman "Aku akan menjadikan penolong baginya, yang sepadan dengan dia" (Kejadian 2:18). Kata sepadan berarti "cocok, mampu, bisa menyesuaikan diri, pelengkap, atau sesuai". Dengan kata lain, Tuhan berkata, "Marilah menjadikan seorang penolong yang cocok untuk Adam (atau untuk manusia). ${ }^{7}$ Keduanya menjadi satu dalam pernikahan, maka seorang laki-laki disebut sebagai suami, seorang wanita disebut isteri. Suami adalah pasangan dari isteri, begitu sebaiknya isteri adalah pasangan dari suami. Mereka menjadi satu dalam pernikahan dan secara umum disebut pasangan suami isteri (pasutri).

Perjanjian pernikahan adalah lembaga pertama yang diciptakan Allah.Sejak awal, Allah telah menempatkan laki-laki dan perempuan bersama. Dalam pernikahan, laki-laki dan perempuan saling menjadi bagian satu sama lain. Mereka dipersatuakan menjadi satu kesatuan. ${ }^{8}$ Dalam pernikahan, Allah telah memanggil dua orang untuk menjadi satu, disatukan dalam tingkah laku,

5 Larry Christenson, Keluarga Kristen (Malang: Yayasan Persekutuan Betania, 1994),

Billy Joe Daugherty, Pernikahan Yang Kokoh (Jakarta:Metanoia, 2001), 14

Ibid, 3

Billy Joe Daugherty, Pernikahan Yang Kokoh (Jakarta:Metanoia, 2001), 19 
pikiran, cita-cita, dan tujuan. ${ }^{9}$ Pernikahan merupakan rencana Allah untuk manusia sebab rencana Allah untuk manusia adalah bahwa Dia tinggal dalam pernikahan, rumah tangga, dan keluarga itu. ${ }^{10}$ Larry Christenson dalam bukunya, Keluarga Kristen menerangkan tentang pernikahan merupakan Suatu Rahasia Ajaib, yaitu:

Alkitab tidak memandang pernikahan sebagai suatu perjanjian antara dua orang yang dapat dibatalkan semaunya; namun sebaliknya, sebagai suatu rahasia ajaib. Dalam tulisannya kepada orang Efesus Rasul Paulus berkata: "Sebab itu laki-laki akan meninggalkan ayahnya dan ibunya dan bersatu dengan isterinya, sehingga keduanya itu menjadi satu daging." Kemudian ia melanjutkan pesan itu dan berkata: "Rahasia ini besar, tetapi yang aku maksudkan ialah hbungan Kristus dan jemaat" (Efesus 5:31,32). ${ }^{11}$

Di dalam pernikahanlah Tuhan menyatakan kehendaknya terhadap manusia untuk saling berpasang-pasangan. Pertemuan keduanya yang diprakarsai Tuhan (Kejadian 2:22), bertujuan membangun kehidupan dalam rumah tangga, dengan memberikan kriteria dan ketentuan yang berguna untuk dapat saling mengikat demi kebaikan bersama (Kejadian 22:23,24). ${ }^{12}$

\section{Pengertian Keluarga}

Penyatuan antara suami danisteri diwujudkan dalam sebuah keluarga. Keluarga merupakan bagian dari masyarakat yang secara etimologis berasal dari bahasa Jawa Kuno, kaulawarga yang dibentuk dari dua kata Sansekerta: kahula yang berati sanak dan warga yang berati anggota. Jadi keluarga berarti anggota atau warga masyarakat yang masih bersanak ${ }^{13}$. Umumnya keluarga dibedakan menjadi dua bagian yaitu : kelurga inti dan keluarga besar.Keluarga inti yaitu terdiri dari suami, istri dan anak, sedangkan keluarga besar yaitu yang merupakan keturunan dari satu leluhur.

Secara umum pengertian keluarga terdiri dari ayah, ibu dan anakanak. ${ }^{14}$ Ketiganya merupakan bagian inti dalam keluarga yaitu suami, isteri dan anak. Jarot Wijanarko dalam bukunya, Hidup Produktif memaparkan tentang keluarga dengan sebuah pendekatan yang sederhana sehingga mudah dimengerti.

\footnotetext{
9 Ibid, 8

10 Ibid, 13

27

11 Larry Christenson, Keluarga Kristen (Malang: Yayasan Persekutuan Betania, 1994),

${ }^{12}$ Ki Bagus Heruyono, PernikahanAwal PerjalananPanjang (Blitar: Tiberias Blitar Publishing, 2011), 5

13 Aliceginting.blogspot.com/2010/08/konseling-pastoral-terhadap-anakkorban.html?m=1

14 Oswari, Keluarga Idaman (Jambi: BPK GUNUNG MULIA, 1982), 16
} 
Kekuatan itu ada dalam sarang yang kuat bagi mereka yang memerlukan saat-saat untuk mendapatkan kekuatan baru, dan memulihkan semangat yang pudar dengan kasih yang menggantikan hati yang terluka. Keluarga adalah sarang yang kuat. Ini adalah tempat di mana saya 'pulang' dan diterima. Bagian inti dari keluarga adalah isteri atau suami (pasangan). Sarang yang satu ini tidak tergantikan dengan hal lain karena keintiman antara dua jiwa dan dua tubuh tidak bisa seintim suami isteri dalam pernikahan yang benar dan harmonis. Oleh karena itu, orang jawa memiliki filosofi bahwa isteri adalah belahan nyawa atau separuh jiwa (garwo=sigaring nyowo) ${ }^{15}$

Keluarga memenuhi sejumlah fungsi yang sangat penting. Pertama, dalam keluarga kebutuhan akan kasih sayang terpenuhi. Bagi suami dan isteri, keluarga juga menyediakan sarana yang tepat untuk kebutuhan seksual yang memuaskan. ${ }^{16}$ Fungsi keluarga adalah melahirkan dan membesarkan anak. Keluarga juga berfungsi sebagai unit ekonomi yang efisien. Akhirnya, keluarga adalah arena yang kecil di mana ide-ide dan praktek-praktek keagamaan, filosofi, dan sosial diajarkan dan diuji. ${ }^{17}$

Dari beberapa penjelasan diatas tentang keluarga, maka dapat disimpulkan bahwa keluarga merupakan dua insani yaitu laki-laki dan perempuan yang dipersatukan oleh Tuhan dalam ikatan pernikahan. Dari dua insani (suami/isteri) tersebut terlahir yang disebut anak, sebagai hasil buah cinta kasih diantara keduanya dan mereka menjadi satu kesatuan dalam keluarga. Keluarga merupakan suatu kekuatan di dalam kehidupan, dimana diantara satu dengan lainnya saling melengkapi dan menguatkan. Keluarga juga merupakan wadah dan sarana untuk saling berproses di antara satu dengan yang lain dalam kehidupan menuju kedewasaan yang matang.

Keluarga merupakan satu kesatuan dari keberbedaan, sebab diawali dari penyatuan dua individu (laki-laki dan perempuan) yang memiliki keberbedaan dari segenap aspek kehidupan. Bahkan, sering tidak menyadari akan perbedaan yang ada. Kecenderungannya adalah saling berusaha untuk mengubah satu sama lain, namun menolak atau kurang bisa menerima perbedaan masingmasing. Sehingga, perbedaan tersebut yang sering menimbulkan konflik dalam keluarga. Muncullah istilah yang disebut disharmonisasi keluarga yang disebabkan oleh tidak memahaminya perbedaan di dalam keluarga.

Dalam Kamus Besar Bahasa Indonesia, kata harmoni memiliki arti keselarasan; keserasian. ${ }^{18}$ Harmonis ialah bersangkut paut dengan (mengenai)

15 Jarot Wijanarko, Hidup Produktif (Yogyakarta: ANDI, 2012), 117

16 Paul D. Meier, dkk, Pengantar Psikologi dan Konseling Kristen 2 (Yogyakarta: ANDI, 2004), 213

17 Ibid, 213

18 Surayin, Kamus Umum Bahasa Indonesia (Bandung: Yrama Widya, 2001), 143 
harmoni; selaras; serasi. ${ }^{19}$ Setiap keluarga mendambakan sebuah keluarga yang harmonis. Jadi, Keluarga yang harmonis ialah keluarga yang menajaga suasana harmonis, saling hormat-menghormati dan saling ketergantungan serta saling membutuhkan sangat perlu untuk dipelihara. ${ }^{20}$ Djohan Kusnaidi dalam bukunya, Pernikahan Yang Menuju Keharmonisan Optimal menuliskan pentingnya keluarga.

Selain menyebabkan munculnya manusia-manusia baru dalam dunia di keluarga, demikian juga kehidupan kasih, keindahan dan kekuatan yang dahsyat untuk memotivasi dan menopang karir dan pelayanan seseorang amatlah ditentukan oleh keluarga. Sebaliknya dari keluarga yang tidak berfungsi akan menghasilkan ketidak optimalan hingga sampai pada kehancuran di dalam karir maupun di dalam pelayanan. Masa depan keluarga, karir dan pelayanan setiap anak-anak dalam sebuah keluarga sangat ditentukan oleh kebijakan pemimpin keluarga di dalam menyikapi arti pentingnya keluarga. ${ }^{21}$

Dari penjelasan diatas dapat disimpulkan bahwa, betapa pentingnya peranan keluarga di dalam kehidupan, karena keluarga merupakan motor penggerak utama di dalam karir, pertumbuhan iman dan segenap kehidupan. Oleh karenanya, menjaga keharmonisan keluarga sangatlah penting dan menjadi tugas dari setiap anggota keluarga. Dalam hidup berdampingan diantara dua individu yang memiliki keberbedaan tentunya akan terjadi yang disebut konflik. Hal tersebut juga bisa terjadi dan dialami oleh pasangan suami isteri yang bersatu dalam keluarga. Konflik antara suami dan isteri, seorang ayah dengan anak, seorang ibu dengan anak, atau diantara anak-anak.

\section{Pengertian Konflik}

Pengertian tentang konflik banyak dijelaskan dari berbagai sudut pengertian. Menurut KUBI (Kamus Umum Besar Indonesia), pengertian konflik ialah perselisihan; pertentangan; percekcokan. ${ }^{22}$ Konflik dilatarbelakangi oleh perbedaan ciri-ciri yang dibawa individu dalam suatu interaksi. Perbedaan-perbedan terebut diantaranya adalah menyangkut ciri fisik, kepandaian, pengetahuan, adat istiadat, keyakinan, dan lain sebagainya. Dalam budaya Amerika masa kini, pengajuan tuntutan ke pengadilan menggantikan interaksi antar pribadi secara langsung. Akibatnya, konflik mungkin dipandang sebagai masalah substantif, tetapi tidak pernah dilihat sebagai masalah relasi

19 Ibid

20 Oswari, Keluarga Idaman (Jambi: BPK GUNUNG MULIA, 1982), 15

21 Djohan Kusnadi, pernikahan Yang Menuju Keharmonisan Optimal (Jakarta: Panca Jaya, 2005), 110

22 Surayin, Kamus Umum Bahasa Indonesia (Bandung: Yrama Widya, 2001), 225 
antar pribadi. ${ }^{23}$ Sikap lebih mengutamakan pemenuhan hak pribadi telah menghilangkan kepedulian terhadap kebaikan bagi seluruh masyarakat. Maka dari pengertian di atas dapat disimpulkan bahwa, pengertian konflik adalah suatu pertentangan yang terjadi antara dua individu atau pihak dalam rangka berusaha mempertahankan kebenaran, eksistensi dan prinsip masing-masing pihak.

Banyak hal yang dapat menimbulkan konflik dalam keluarga dan menjadi faktor-faktor penyebab konflik keluarga. M. S Hadisubrata dalam bukunya, Keluarga dalam Dunia Modern memaparkan masalah-masalah yang timbul dalam pernikahan. Masalah-masalah yang dimaksud adalah sebagai berikut: ${ }^{24}$

- Harapan-harapan yang tidak realistis.

Harapan-harapan ini muncul pada masa romantik, yakni selama pacaran dan tahun-tahun pertama pernikahan. Harapan-harapan yang tidak realistis ini misalnya, mereka merasa bahwa pernikahan mereka akan membuat mereka bahagia selamanya, hubungan seksual mereka sellu menyenangkan, mereka tidak pernah kesepian lagi, dengan pekawinan ini pasangan mereka akan berubah menjadi lebih baik, dan sebagainya. Ketika harapan-harapan ini tidak terpenuhi, maka dapat menimbulkan kekecewaan bagi kedua belah pihak.

- Sumber Konflik dalam pernikahan.

Sumber konflik ini dapat mencakup dua hal. Pertama, konflik yang bersumber pada kepribadian pasangan yang biasanya disebabkan ketidakmatangan kepribadian, adanya sifat-sifat kepribadian yang tidak cocok untuk menjalin hubungan pernikahan misalnya, pemabuk, penjudi, egois, tertutup, keras kepala dan lain-lain, dan adanya kelainan mental misalnya homoseks atau lesbian, schizophrenia, sadisme dan lain-lain. Kedua, konflik yang bersumber pada hal-hal yang erat kaitannya dengan perkawinan, misalnya, masalah keuangan, kehidupan dan tempramen sosial, pendidikan anak, agama, hubungan dengan mertua dan ipar, penyelewengan dalam hubungan seksual dan lain-lain.

- Ketidakpuasan seksual.

Hal ini dapat disebabkan sebagai akibat dari kekecewaan terhadap pasangan yang dapat mengakibatkan mengendornya hubungan pribadi suami-isteri. Ketidakpuasan dalam hubungan seksual ini dapat juga disebabkan oleh anggapan yang salah (tabu) mengenai aktivitas seksual. Hambatan-hambatan yang menyebabkan ketidakpuasan seksual dapat meliputi hambatan psikologis, misalnya rasa takut dan cemas akan kehamilan, dan hambatan fisik misalnya, dalam bentuk kelainan seksual.

23 Robert Banks and R. Paul Stevens, The Complete Book of Everyday Christianity (Bandung: Kalam Hidup, 1997), 344 2008), 30-35

24 M. S Hadisubrata, Keluarga dalam Dunia Modern (Jakarta: BPK Gunung Mulia, 
- Masalah penyesuaian diri terhadap keluarga.

Latar belakang keluarga yang berbeda, cara bergaul, cita-citanya tentang rumah tangga, sikap mereka terhadap keluarga kedua belah pihak, tetang hubungan saudara ipar, dan lain-lain.

- Masalah pengendalian keuangan.

Hasil survey para ahli menyatakan lebih $50 \%$ perceraian disebabkan karena masalah keuangan alam keluarga. ${ }^{25}$ Konflik muncul karena masalah keuangan yang disebabkan oleh perencanaan dan pengaturan belanja yang buruk.

- Masalah harapan-harapan.

Harapan-harapan mengenai soal keuangan, anak, cita-cita, masa depan, masalah seksual dan lain-lain dalam rumah (keluarga) yang dibina.

- Kehidupan rohani (spiritual life).

Keanggotaan gereja, doa dan kebaktian bersama, peran serta atau partisipasi dalam gereja, dan lain-lain.

Masalah umum yang membuat pasangan suami-isteri datang meminta konseling antara lain: konflik peranan, yaitu pasangan suami-isteri tidak memahami perbedaan peranan antara suami dan isteri dengan jelas secara alkitabiah. Masalah keuangan, yaitu masalah keuangan yang disebabkan oleh perencanaan dan pengaturan keuangan rumah tangga yang buruk. Masalah seksual, yaitu mereka tidak merasakan kepuasan dalam hubungan seksual seperti yang masing-masing pasangan inginkan/harapkan. Konflik dengan mertua, yaitu perbedaan pendapat dan perbedaan latar belakang dengan mertua yang berakibat pada perelisihan. Masalah dalam membesarkan anak, yaitu yang disebabkan oleh perbedaan dalam menjadi oran tua di rumah di mana suami dan isteri dibesarkan. ${ }^{26}$

Adapun dampak-dampak yang terjadi dari beberapa jenis konflik dalam keluarga yang disebabkan dari hal-hal di atas menurut Yakub B. Susabda ialah: $:^{27}$

- Hubungan Orang Tua dan Anak

Dampak. Melemahnya dan atau rusaknya komunikasi orang tua dan anak. Perkembangan kepribadian anak yang tidak sehat (rendah diri, penghargaan yang kurang terhadap diri sendiri, jiwa yang ragu-ragu). Terjerat pada pola hidup yang selalu menibukkan diri. Cenderung membuat hukum sendiri. Kesulitan untuk membangun keintiman dengan orang yang dekat. ${ }^{28}$

25 Vivian. A. Soesilo, Bimbingan Pranikah Cetakan Ke 3 (Malang: SAAT, 2001), 118

${ }^{26}$ Paul D. Meier, dkk, Pengantar Psikologi dan Konseling Kristen 2 (Yogyakarta: ANDI, 2004), 220

27 Yakub B. Susabda, PelayananKonseling Melalui Telepon (Yogyakarta: ANDI, 2007), 19-31

28 Ibid, 20 
- Penyelewengan dalam pernikahan

Dampak. Emosional: perasaan bersalah, cemburu, takut, cemas, tidak aman, mengutuk diri, marah, dan keinginan untuk membalas. Hubungan antar pribadi: retaknya pernikahan, gangguan dalam pekerjaan atau karir, menutup diri, naiknya frekuensi pertengkaran. Spiritual: kemerosotan dalam kehidupan rohani, mempersalahkan Tuhan, mempertanyakan keadilan dan kasih Tuhan. fisik: kehamilan, penyakit kelamin, kebekuan gairah seks (frigidity). ${ }^{29}$

- Keluarga yang sering bertengkar.

Dampak. Tidak memiliki gairah dalam kehidupan, menurunnya semangat kerja dan keinginan untuk lebih banyak di luar rumah. Berkembangnya pikiran negatif terhadap pasangan, sehingga menutup kesempatankesempatan untuk berubah dan bertumbuh sebagai pribadi dewasa yang diperkenan Allah (memberikan label pada pasangannya, misal: pribadi yang menyebalkan, dsb). Sengaja membawa diri ke dalam pencobaan dengan memakai kata-kata yang memancing pasangannya untuk berbuat dosa. ${ }^{30}$

- Non sexual abuse (penganiayaan fiik dan atau emosi, biasanya dalam sikap dan kata-kata dengan sengaja ataupun tidak sengaja menimbulkan dampak luka-luka batin).

Dampak. Perasaan rendah diri. Kemampuan dalam kehidupan sosial terhambat. Perasaan tidak aman, ketidakstabilan emosi, mudah tersinggung dan meledak-ledak. Kecenderungan menjadi orang yang mudah memaksakan kehendak dengan cara seperti yang dilakukan orang terhadapnya. Menghindar, tidak peduli dan kadang membalas. ${ }^{31}$

Ketika menyelesaikan konflik dalam keluarga, masing-masing keluarga memiliki cara yang berbeda-beda. Ketika suatu krisis atau masalah terjadi di dalam keluarga, maka keluarga tersebut menanggapinya dengan cara-cara tertentu. Cara-cara menyelesaikan konflik di dalam keluarga menggunakan cara yang diturunalihkan dari keluarga ke keluarga. Atau cara-cara tersebut merupakan hasil dari sejumlah pengaruh baru atas keluarga itu.Sebuah keluarga dapat mengembangkan cara baru dalam rangka mengatasi persoalan baru. Keluarga dalam mengatasi masalah beraneka ragam cara. Cara-cara tersebut mungkin positif atau negatif karena kecenderungan umumnya ialah bahwa keluarga menggunakan cara-cara ini untuk menyesuaikan diri dengan persolan dan krisis yang sedang dihadapi. ${ }^{32}$

29 Ibid, 23-24

30 Ibid, 28 2007), 31

31 Yakub B. Susabda, PelayananKonseling Melalui Telepon (Yogyakarta: ANDI,

${ }^{32}$ Oliver Mc Mahan, Gembala Jemaat Yang Sukses (Jakarta: Sinode GBI, 2002), 183 
Sejumlah cara-cara mengatasi konflik yang positif dan kudus ialah ketika keluarga menanggapinya dengan lebih mendekatkan diri kepada Tuhan. mereka mencari bantuan dari teman atau gembala jemaat. Keluarga tersebut dapat berlibur atau mengadakan perjalanan. Mereka dapat belajar untuk duduk bersama dan memecahkan persoalannya bersama-sama. Semua dapat meningkatkan renungan, doa, dan studi Alkitab. ${ }^{33}$

Keluarga yang mengatasi konflik dengan cara-cara yang negatif atau tidak kudus. Masing-masing anggota keluarga saling mengasingkan diri satu sama lain. Ada keluarga yang merasa bahwa cara terbaik mereka dalam mengatasi masalah ialah dengan saling memaki dan berteriak. Keluarga lain mungkin akan mengasingkan atau mengkambing-hitamkan salah satu anggota keluarga. Kadangkala kekerasan digunakan sebagai metode untuk mengatasi masalah. ${ }^{34}$

\section{Pengertian Konseling}

Berbicara tentang konseling, maka yang muncul di dalam benak pikiran orang pada umumnya, konseling merupakan suatu bidang keilmuan yang di pelajari di dalam dunia akademik. Oleh sebab itu hanya orang-orang yang mempelajari ilmu konseling saja yang mampu melakukan kegiatan tersebut. Sehingga berpendapat bahwa orang awam yang tidak pernah mempelajari ilmu konseling tidak bisa melakukan konseling. Konsep pemikiran yang demikian adalah keliru, sebab kegiatan konseling sebenarnya terjadi ketika dua individu terlibat dalam komunikasi dan terjadi interaksi di antara dua individu maupun kelompok.Pengertian konseling banyak dikutip dan ditulis dalam beberapa pengertian. E. P Gintings, dalam bukunya Konseling pastoral, menjelaskan secara etimologis istilah Counseling, yaitu:

Counseling dalam kamus Webster's New Collegiate Dictionary disebutkan berasal dari istilah Latin yaitu consilium yang berati perundingan, pertimbangan, atau musyawarah. Dalam istilah counsilium terdapat unsur dengan atau bersama orang lain; ditambah unsur memahami atau mengambil sari dari pembicaraan, pemikiran, atau ide orang lain. Seterusnya dalam kamus tersebut diperoleh keterangan bahwa secara etimologis, kata counsel berasal dari dua kata yaitu coun dan sel. Kata sel berasal dari Anglo Saxon yaitu sellan yang berarti menjual, tetapi juga berarti membebaskan, menyelamatkan ${ }^{35}$.

Selanjutnya dari penjelasan kata Counseling diatas E. P. Gintings menyimpulkan pengertian konseling, yaitu:

33 Ibid, 183

34 Ibid, 183

35 E. P. Gintings, Konseling Pastoral (Bandung: Jurnal Info Media, 2009), 10 
Counseling adalah suatu perembugan, perundingan yang diadakan bersama atau dengan orang lain untuk mencari suatu jalan keluar atau putusan yang menyelamatkan atau membebaskan sehingga konseling tidak berarti suatu nasehat yang bersifat menolong terhadap orang lain. Dalam perkembangan selanjutnya, konseling menjadi sebuah istilah mengenai kegiatan berbagai macam prosedur kegiatan yang mencakup upaya-upaya seperti memberi nasehat, dorongan, informasi, dan menganalisa sesuatu masalah atau fakta ${ }^{36}$.

Jika memahami pengertian konseling di atas maka, proses konseling menjadi suatu kegiatan yang sangat populer terjadi dikalangan masyarakat umum karena ada hal-hal kegiatan yang mengandung unsur-unsur konseling dalam percakapan yang dilakukan di kalangan masyarakat umum. Konseling sebagai suatu hubungan yang bersifat manusiawi, yang terjadi karena seseorang ingin berusaha membantu orang lain, agar orang itu mengerti dan menyelesaikan permasalahan-permasalahan yang berkaitan dengan penyesuaian individu dengan keadaan-keadaan/situasi lingkungannya

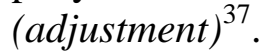

Konseling atau penyuluhan adalah proses pemberian bantuan yang dilakukan oleh seorang ahli (disebut konselor/pembimbing) kepada individu yang mengalami sesuatu masalah (disebut konseli) yang bermuara pada teratasinya masalah yang dihadapi $\operatorname{klien}^{38}$. Di dalam konseling terjadi percakapan atau dialog antara dua individu yang aktif dan efektif. Seseorang yang memberikan bantuan maupun sumbangsih pemikiran, nasehat kepada orang lain dalam menyelesaikan suatu masalah sehingga orang tersebut menemukan jalan keluar/solusinya maka, kegiatan tersebut bisa disebut konseling. Dalam proses konseling terjadi hubungan timbal balik dalam percakapan antara dua individu. Percakapan yang dimaksud ialah percakapan yang aktif sehingga terjadi interaksi diantaranya. Di dalam konseling dibutuhkan percakapan yang aktif diantara kedua belah pihak (konselor dan konseli) sehingga proses konseling akan berjalan dengan baik.

\section{Pelayanan Konseling Kristen}

Pelayanan konseling tidak hanya dilakukan oleh hamba Tuhan atau konselor yang profesional, tetapi juga dapat dilakukan oleh setiap orang percaya yang dipanggil untuk mengasihi dan menolong orang lain ${ }^{39}$. Dalam realita kehidupan sehari-hari, orang-orang Kristen juga sudah melakukan percakapan konseling dengan orang lain.Pengertian Konseling Kristen lebih spesifik kepada pelayanan konseling yang berdasarkan kaidah-kaidah

36 Ibid, 10

37 E. P. Gintings, Konseling Pastoral (Bandung: Jurnal Info Media, 2009), 11

38 Id.m.wikipedia.org/wiki/konseling

39 Yakub B. Susabda, Pelayanan Konseling Melalui Telelpon (Yogyakarta: ANDI, 2007), 103 
Kekristenan. Yakub B. Susabda, dalam bukunya Pelayanan Konseling Melalui Telepon menjelaskan bahwa:

Konseling adalah hubungan timbal balik antara dua individu (yakni konselor yang berusaha menolong atau membimbing dan klien yang membutuhkan bimbingan) dalam suasana percakapan yang serasi/tepat (conducive atmosphere) yang memungkinkan klien mengenali dirinya, mengerti apa yang sedang terjadi dengan dirinya, dan memiliki kemampuan untuk melihat dan mencapai tujuan hidupnya dalam relasi dan tanggung jawab kepada Tuhan, sesuai dengan kemampuan dan talenta yang diberikn Tuhan kepadanya ${ }^{40}$

Dalam konseling Kristen nampak dengan jelas kaidah-kaidah yang sesuai dengan Alkitab dalam menolong atau membimbing seseorang dalam konseling. Sehingga seseorang akan dibawa kepada pemahaman Alkitab dalam menyelesaikan masalah-masalah yang terjadi dengan dirinya. Konseling Kristen bukan semata-mata diadaptasikan begitu saja dari ilmu sekuler, melainkan memberi penegasan bahwa praktek konseling telah dilakukan oleh tokoh-tokoh Alkitab jauh sebelum disiplin ilmu konseling ada.

Oleh sebab itu, diperlukan pendekatan untuk membawa tatanan dari pendekatan-pendekatan konseling Kristen agar tidak menimbulkan kebingungan (eklektis) sebagai berikut: "Harus bergantung kepada Allah",ada Allah pribadi yang berpikir, merasakan, memilih, dan bukan kepada yang lain $^{41}$. Selanjutnya, E. P. Gintings dalam bukunya, Konseling Pastoral menjelaskan pula hal mendasar yang perlu diketahui dalam konseling Kristen bahwa, konseling pastoral harus berakar pada kesadaran triolog sebagai Allah yang berpribadi, sehingga dalam proses konseling pastoral ada konselor dan konseli serta di tengah-tengah mereka hadir Allah di dalam Roh Kudus yang mempengaruhi konselor maupun konseli. ${ }^{42}$

Tidak dapat dipungkiri bahwa penyelesaian masalah melalui konseling sekuler merupakan salah satu cara mendapatkan solusi. Namun ada perbedaan yang sangat mendasar antar konseling Kristen dan konseling sekuler. Mulai dari metode penyampaian, dasar teori yang digunakan bahkan prinsip-prinsip yang digunakan. Konseling Kristen memiliki prinsip yang berbeda dengan konseling sekuler. ${ }^{43}$ Sebenarnya, konseling Kristen maupun konseling sekuler memiliki hasrat dan harapan yang sama untuk menolong manusia megatasi permasalahan mereka, menemukan arti dan kebahagiaan dalam hidup, mengenali diri dan pribadi mereka sendiri lebih dalam, dan menjadi

40 Yakub B. Susabda, Pelayanan Konseling Melalui Telelpon (Yogyakarta: ANDI, 2007), 101

41 E. P. Gintings, Konseling Pastoral (Bandung: Jurnal Info Media, 2009), 19

42 Ibid

43 Ki Bagus Heruyono, Landasan Teologis dan Seni Pelayanan Konseling (Blitar: diktat SOP-GTI), 7 
manusia yang sehat, yang berfungsi sepenuhnya dan dapat menempatkan diri serta merespon dengan tepat secara mental dan emosional. Secara tehnik, konseling Kristen dan konseling sekuler memang dapat dikatakan hampir tidak ada perbedaannya. Namun prinsip atau konsep antara konseling Kristen dan sekuler, menghasilkan presuposisi yang berbeda dalam proses konseling.

Collins menyebutkan beberapa presuposisi dasar (pra-anggapan) yang membedakan antara konseling Kristen dan konseling sekuler, ialah ${ }^{44}$ :

1. Orientasi dan Sumber Pengetahuan Konseling

Konseling sekuler berorientasi pada manusia (anthropocentris) dan sumber pengetahuan adalah berasal dari akal budi dan pengalaman manusia (humanisme). Sedangkan Konseling Kristen berorientasi pada Tuhan (theocentris), karena itu pengetahuan konseling bersumber dari Allah yang telah menyatakan Diri-Nya kepada manusia. Oleh karena itu konselor Kristen percaya bahwa melalui Alkitab Allah telah memberikan prinsip-prinsip bagaimana seharusnya kita hidup.

2. Tujuan Konseling

Konseling sekuler bertujuan untuk menolong orang yang dikonseling (klien) mendapatkan kebahagiaan hidup. Sebaliknya, konseling Kristen memiliki tujuan utama agar klien dapat hidup menyenangkan Tuhan, yaitu melakukan apa yang Tuhan kehendaki sesuai dengan FirmanNya, sehingga melalui ketaatan kepada Tuhan dan Firman-Nya klien akan membuahkan kebahagiaan hidup yang sejati.

3. Prinsip Konseling

Konseling sekuler memakai prinsip-prinsip yang lahir dari hikmat dan filsafat manusia untuk menjawab semua kebutuhan-kebutuhan yang diingini manusia. Prinsip-prinsip konseling Kristen diberkan oleh Tuhan melalui Alkitab, Roh Kudus yang tinggal dalam hati setiap orang percaya dan kuasa doa, agar kehendak Tuhan terjadi dalam hidup klien.

4. Kebenaran Moralitas

Kebenran moralitas Konseling Sekuler ditentukan oleh situasi etika masyarakat saat itu, yang dapat mengalami pergeseran-pergeseran atau perubahan. Sedangkan kebenaran moralitas Konseling Kristen berakar pada kebenaran Alkitab yang tidak pernah luntur atau berubah.

\section{Dasar Teologis Pelayanan Konseling Kristen}

Secara teologis, pelayanan konseling kristen merupakan suatu bentuk pelayanan yang berpusatkan kepada Alkitab sebagai landasan utamanya. Artinya, dalam pelayanan konseling kristen menggunakan kaidah-kaidah maupun prinsip-prinsip yang berlandaskan kebenaran Alkitab sebagai

\footnotetext{
${ }^{44}$ www.my-lifespring.com/artikel/konseling_kristen_dan_konseling_sekuler.php
} 
pedoman di dalam konseling. Teologi merupakan isi dari pelayanan konseling, dengan Alkitab sebagai obyek sekaligus sumber kajian teologi. Artinya dalam pelayanan konseling Kristen, Alkitab menjadi satu-satunya dasar pelayanan, dimana setiap pelayanan berdasarkan pada kebenaran Alkitab, dan dalam pelayanan hanya isi Alkitab yang dibicarakan selain pengetahuan sekuler sebagai pendukung konseling. Teologi sebagai isi dari pelayanan konseling kristen, berupaya menghadirkan Allah dalam proses konseling, sehingga pelayanan konseling Kristen yang bersumber kepada Alkitab sebagai landasan utamanya, akan menuntun konseli mengalami pertolongan dan solusi dari Allah dalam menghadapi persoalan hidup.

Dalam pelayanan konseling kristen yang menjadikan Firman Tuhan (Alkitab) sebagai landasan teologis, Paulus menulis di dalam Kolose 1:28,'Dialah yang kami beritakan, apabila tiap-tiap orang kami nasihati dan tiap-tiap orang kami ajari dalam segala hikmat, untuk memimpin tiap-tiap orang kepada kesempurnaan dalam Kristus", bahwa interaksi verbalnya dengan orang-orang (konseling?) selalu didisain untuk memperkenalkan kedewasaan Kristen. Dengan demikian konseling alkitabiah akan menjadi sebagai strategi utamanya yaitu memperkenalkan kedewasaan rohani dan psikologi". ${ }^{5}$ Ini berarti konseling Kristen sebagai alat Tuhan untuk menuntun orang-orang menuju pengenalan kepada Tuhan secara pribadi, sehingga masing-masing orang memiliki hubungan intim bersama Tuhan dan menaruh pengharapannya hanya kepada Tuhan dalam menyelesaikan persoalan pribadi berdasar pada Alkitab.

Perjanjian Baru mencatat pelayanan Yesus Kristus tidak hanya berkhotbah dan mengajar, namun juga melalui pendekatan pelayanan konseling. Sebagai contoh, percakapan Yesus dengan seorang wanita Samaria yang tidak memiliki kepuasan hidup dalam Yohanes 4, melalui teknik koneling Yesus berhasil menolong wanita Samaria melihat inti persoalannya. ${ }^{46}$ Selain itu Firman Tuhan juga menjiwai pelayanan konseling Kristen. Hal ini berkaitan dengan tujuan konseling, yaitu menolong, mendampingi, membimbing dan menemukan solusi dimana Firman Tuhan sebagai landasan teologis pelayanan konseling Kristen.

\section{Konseling Kepada Pasangan Suami Isteri}

Konseling kepada pasangan suami isteri lebih spesifik dilakukan kepada sepasangan suami isteri yang terikat di dalam pernikahan. Jadi konseling kepada pasangan suami isteri sama halnya dengan konseling pernikahan karena pasangan suami isteri terikat dalam suatu pernikahan. Konseling perkawinan pada awalnya dilaksanakan oleh karena kebutuhan dan

45 Larry Crabb, Konseling yang Efektif dan Alkitabiah (Yogyakarta: ANDI, 1995), 18

46 Ki Bagus Heruyono, Landasan Teologis dan Seni Pelayanan Konseling (Blitar: diktat SOP-GTI), 10 
permintaan pasangan suami-isteri. Mereka memiliki sejumlah masalah sehubungan dengan perkawinan mereka dan berkeinginan untuk mengonsultasikan masalahnya ke konselor.

Konseling perkawinan memiliki beberapa istilah, yaitu couples counseling, marriage counseling, dan marital counseling. Istilah-istilah ini dapat digunakan secara bergantian dan memiliki makna yang sama. ${ }^{47}$ Latipun dalam bukunya Psikologi Konseling mengutip pendapat Klemer memaknakan konseling perkawinan sebagai konseling yang diselenggarakan sebagai metode pendidikan, metode penurunan ketegangan emosional, metode membantu partner-partner yang menikah untuk memecahkan masalah dan cara menentukan pola pemecahan masalah yang lebih baik. ${ }^{48}$ Dikatakan sebagi metode pendidikan karena konseling perkawinan memberikan pemahaman kepada pasangan yang berkonsultasi tentang diri, pasangannya, dan masalahmasalah hubungan perkawinan yang dihadapi serta cara-cara yang dapat dilakukan dalam mengatasi masalah perkawinannya.

Penurunan ketegangan emosional dimaksudkan bahwa konseling perkawinan dilaksanakan biasanya saat kedua belah pihak berada pada situasi emosional yang sangat berat (akut). Dengan konseling, pasangan dapat melakukan ventilasi, dengan jalan membuka emosionalnya sebagai katarsis terhadap tekanan-tekanan emosional yang dihadapi. ${ }^{49}$ Konseling perkawinan dan konseling keluarga memiliki perbedaan, para ahli biasanya membedakannya. Perbedaan yang terdapat di keduanya ialah terletak pada penekanan masing-masing jenis berhubungan dengan orang-orang yang terlibat dalam proses konseling. Secara umum konseling keluarga dibatasi sebagai konseling yang berhubungan dengan masalah-masalah keluarga, misalnya hubungan peran di keluarga, masalah komunikasi, tekanan dan peraturan keluarga, dan ketegangan orang tua-anak. Sementara konseling perkawinan lebih menekankan pada masalah-masalah pasangan (suami dan isteri).

Menurut Latipun, konseling perkawinan dilaksanakan tidak bermaksud untuk mempertahankan suatu keluarga. Konselor berpandangan bahwa dirinya tidak memiliki hak untuk memutuskan cerai atau tidak sebagai solusi terhadap masalah yang dihadapi pasangan. ${ }^{50}$ Latipun mengutip pendapat Brammer dan Shostrom mengemukakan bahwa konseling perkawinan dimaksudkan membantu klien-kliennya untuk mengaktualkan dari yang menjadi perhatian pribadi, apakah dengan jalan bercerai atau tidak. ${ }^{51}$ Dalam konseling

47 Latipun, Psikologi Konseling (Malang: Universitas Muhammadiyah Malang, 2003),

48 Latipun, Psikologi Konseling (Malang: Universitas Muhammadiyah Malang, 2003), 188

49 Ibid

50 Ibid, 191

51 Ibid 
perkawinan, konselor membantu klien (pasangan) untuk melihat realitas yang dihadapi, dan mencoba menyusun keputusan yang tepat bagi keduanya. Keputusannya dapat berbentuk menyatu kembali, berpisah, cerai, untuk mencari kehidupan yang lebih harmoni, dan menimbulkan rasa aman bagi keduanya.

Latipun juga mengutip secara terperinci tujuan jangka panjang konseling perkawinan menurut Huff dan Miller adalah sebagai berikut: (1) meningkatkan kesadaran terhadap dirinya dan dapat saling empati di antara patner. (2) meningkatkan kesadaran tentang kekuatan dan potensinya masingmasing. (3) meningkatkan saling membuka diri. (4) meningkatkan hubungan yang lebih intim. (5) mengembangkan keterampilan komunikasi, pemecahan masalah, dan mengelola konfliknya. ${ }^{52}$

Dari beberapa penjelasan diatas tentang tujuan konseling pasangan suami-isteri adalah membantu pasangan (suami-isteri) dalam menyelesaikan permasalahan yang muncul dalam hubungan perkawinan mereka, supaya sedapat mungkin mereka mampu memertahankan hubungan perkawinannya dengan saling memahami, mengerti dan menerima perbedaan diantara mereka sehingga mendapatkan kehidupan yang lebih harmonis dan keutuhan dari sebuah keluarga sesuai dengan kebenaran firman Tuhan.

Ada beberapa macam bentuk pelayanan konseling yang dapat dilakukan kepada pasangan suami isteri dalam menyelesaikan permasalahan. Paul D. Meier menuliskan bukunya, Pengantar Psikologi dan Konseling Kristen menjelaskan ada beberapa bentuk pelayanan konseling kepada pasangan suami isteri. ${ }^{53}$ (1) Konseling pernikahan secara individual hanya satu anggota pasangan yang datang untuk meminta konseling, dengan harapan ia bisa menemukan cara yang lebih sehat untuk mengatasi masalahnya. ${ }^{54}$ (2) Collaborative marital counseling konseling pernikahan kolaboratif, suami dan isteri menemui konselor yang berbeda. Konselor-konselor itu kadang-kadang bertemu untuk membicarakan kasus itu dan kemudian bekerjasama satu sama lain, membandingkan hasil konselingnya dan merencanakan strategi intervensi yang sesuai. $^{55}(3)$ Dalam konseling pernikahan yang berurutan, seorang konselor menemui suami dan isteri secara terpisah. ${ }^{56}$ (4) Dalam konseling pernikahan gabungan dan bersama-sama kedua pasangan kadang-kadang ditemui secara terpisah oleh seorang konselor, tetapi mereka juga ditemui bersama-sama. $^{57}$ 191

52 Latipun, Psikologi Konseling (Malang: Universitas Muhammadiyah Malang, 2003),

53 Paul D. Meier, dkk, Pengantar Psikologi dan Konseling Kristen 2 (Yogyakarta: ANDI, 2004), 215

54 Ibid, 215

55 Ibid

56 Ibid

57 Ibid 


\section{KESIMPULAN}

Pelayanan konseling Kristen kepada pasangan suami-isteri dalam menyelesaikan konflik keluarga adalah langkah penting yang harus segera dilakukan oleh setiap pelaku gereja (hamba Tuhan) yang berperan sebagai konselor. Sebab ada beberapa hal yang menjadi pertimbangan bahwa pelayanan konseling Kristen kepada pasangan suami-isteri dalam menyelesaikan konflik adalah penting dan maka dapat ditarik simpulan sebagai berikut:

1) Pelayanan konseling Kristen sebagai representatif Tuhan Yesus Kristus, Sang Konselor Agung, seharusnya pelayanan konseling Kristen dilakukan dengan sungguh-sungguh dan penuh tanggung jawab sebagai bentuk meneladani figure Tuhan Yesus dalam melakukan konseling kepada umat manusia. Sehingga peran pelayanan konseling Kristen kepada jemaat khususnya kepada pasangan suami-isteri dalam menyelesaikan konflik keluarga memberikan dampak yang besar secara rohani, dimana setiap jemaat dan keluarga Kristen tetap kokoh di dalam iman dan mampu menyelesaikan konflik keluarga dengan baik sesuai prinsip-prinsip Alkitabiah.

2) Pelayanan konseling Kristen kepada pasangan suami-isteri dalam menyelesaikan konflik keluarga perlu mendapat perhatian khusus bagi gembala jemaat, gembala bertanggungjawab untuk memperhatikan langsung kegiatan pelayanan konseling Kristen tersebut karena seluruh pembinaan kerohanian jemaat, termasuk pelayanan konseling Kristen menjadi tanggung jawab seorang gembala jemaat. Jika gembala jemaat tidak aktif ada di tempat, maka pendelegasian kepada para pengerja gereja yang telah ditunjuk oleh gembala jemaat untuk melayani konseling Kristen kepada jemaat bisa dilaksanakan dengan sebaik-baiknya dengan penuh tanggung jawab.

3) Pelayanan konseling Kristen kepada pasangan suami-isteri dalam menyelesaikan konflik keluarga menjadisolusi yang tepat di tengah-tengah perubahan dan perkembangan jaman yang semakin kompleks. Sekaligus persoalan dan permasalahan yang dihadapi oleh setiap keluarga juga semakin kompleks sehingga dengan adanya pelayanan konseling Kristen mampu membantu memberikan jawaban dan jalan keluar bagi keluarga yang menghadapi konflik keluarga.

4) Bentuk keseriusan pelayanan konseling Kristen terhadap keluarga dalam menyelesaikan konflik perlu diwujudkan dengan proaktif. Sehingga gereja sebagai pelaku/konselor dari pelayanan konseling Kristen dapat berkontribusi dan berdampak terhadap keluarga yang sedang dalam menghadapi konflik sehingga keutuhan dan keharmonisan keluarga bisa tetap terjaga dengan baik. 
5) Diperlukan kerjasama yang baik antara pihak gereja (gembala dan para pengerja) dengan seluruh jemaat, khususnya kepada pasangan suami-isteri dalam menyelesaikan konflik keluarga untuk aktif melakukan konseling Kristen jika memerlukan konseling dalam menyelesaikan permasalahan maupun konflik keluarga yang tidak dapat terselesaikan secara pribadi. Maka pasangan suami-isteri perlu melibatkan pihak gereja untuk melakukan konseling Kristen dalam menyelesaikan permasalahan atau konflik keluarga.

Setelah melalui kesimpulan, maka di bawah ini adalah rekomendasi untuk pelaku gereja (hamba Tuhan/gembala jemaat) sebagai konselor, sebagai berikut:

1) Kepada gembala jemaat untuk memperhatikan dengan serius permasalahan pelayanan konseling Kristen yang berjalan kurang efektif. Sebab pelayanan konseling Kristen sangat penting bagi jemaat khususnya bagi pasangan suami-isteri dalam menyelesaikan konflik keluarga, agar pasangan suami-isteri memiliki kekuatan dan tetap hidup sesuai prinsipprinsip Alkitabiah dalam menghadapi dan menyelesaikan konflik keluarga. Teladan seorang gembala jemaat adalah Tuhan Yesus Kristus, sehingga pelayanan konseling Kristen kepada jemaat harus meneladani Tuhan Yesus Kristus, yang senantiasa memiliki waktu bagi umatnya yang memerlukan pertolongan di tengah-tengah persoalan hidup. Empati adalah suatu sikap yang rela untuk menempatkan diri pada posisi orang lain (klien). Artinya, kerelaan untuk merasakan apa yang dirasakan orang lain, mengerti apa yang dikehendaki orang lain, melihat apa yang dialami orang lain, dan berpikir dengan apa yang dipikirkan orang lain. Semuanya itu merupakan dasar untuk melakukan pelayanan konseling. Empati merupakan salah satu unsur terpenting dari understanding (sikap penuh pengertian yang dihayati) yang sangat menentukan langkah seseorang untuk melakukan pelayanan konseling. Melalui empati konselor dapat benar-benar memahami apa yang dialami oleh konseli, sehingga pelayanan konseling bisa berjalan dengan efektif. ${ }^{58}$ Para pengerja gereja tidak akan bisa bekerja dengan optimal jika tidak ada job discription yang jelas dari hamba Tuhan (Pendeta) sebagai pemimpin yang mendelegasikan tugas kepada pengerja gereja. Pendelegasian tugas yang jelas sangat membantu para pengerja gereja yang fulltime di gereja untuk melaksanakan tugasnya sesuai tugas dan tanggung jawabnya. Begitu juga pendelegasian tugas untuk pelayanan konseling kepada jemaat harus jelas, sehingga jemaat maupun konseli yang hendak konseling juga mengetahui kepada siapa mereka datang untuk konseling. Pendelegasian tugas kepada konselor hendaknya juga disertai pembekalan kemampuan pengetahuan

$58 \quad 1$ Petrus 3:8 
dan wawasan di bidang konseling sesuai dengan tugas yang diberikannya. Pendelegasian tugas ini menjadi kunci keefektifan pelayanan konseling di gereja, sehingga konselor mengerti dan tahu tugas dan tanggung jawabnya. ${ }^{59}$ Dalam mendelegasikan tugas hendaknya hamba Tuhan (pendeta) juga harus bisa memilih dan menetapkan seorang konselor yang memiliki kepribadian dan berkarakter bisa menjadi teladan dilingkungannya, baik dilingkungan dimana konselor bertempat tinggal maupun di lingkungan gereja supaya konseli. Alangkah baiknya juga Gembala jemaat sebelum memilih dan menetapkan seorang konselor, menilai orang tersebut dilihat dari kehidupan di dalam keluarga sebagai tolak ukurnya. Seorang konselor harus bisa mejadi teladan di dalam keluarganya sebelum dia membimbingan dan menuntun orang lain (konseli). ${ }^{60}$

2) Kepada para pengerja/majelis gereja untuk siap menerima pendelegasian tugas dari gembala jemaat, dalam hal pelayanan konseling kepada jemaat khususnya pasangan suami-isteri. Agar dalam melaksanakan tugasnya dengan segenap hati, sungguh-sungguh dan penuh tanggung jawab kepada Tuhan Yesus sebagai Pemimpin dan Gembala Agung gereja. Dengan demikian, apabila gembala jemaat tidak aktif ada di tempat, maka para pengerja dapat menolong tugas gembala jemaat dalam melaksanakan pelayanan konseling kepada pasangan suami-isteri dalam menyelesaikan konflik keluarga dengan baik.

3) Kepada seluruh jemaat gereja untuk memanfaatkan fasilitas yang telah disediakan oleh pihak gereja, dalam hal ini yaitu pelayanan konseling Kristen. Pelayanan konseling Kristen ini akan membantu jemaat khususnya pasangan suami-isteri dalam menyelesaikan konflik keluarga yang tidak dapat diselesaikan secara pribadi. Sehingga jemaat Tuhan yang adalah keluarga Kristen mampu menyelesaikan permasalahan keluarganya dengan tuntas dan menyeluruh sesuai dengan prinsip-prinsip Alkitab. Diharapkan melalui pelayanan konseling Kristen ini dapat tercipta keluarga Kristen yang harmonis.

4) Kepada Gembala jemaat dan Majelis gereja untuk mengadakan sebuah acara spontanitas kepada setiap jemaat khususnya kepada pasangan suami istri. Acara tersebut diadakan bertepatan dengan hari ulang tahun pernikahan. Tujuan acara tersebut ialah: pertama, mengingatkan kepada pasangan suami istri pada sebuah momen terindah di dalam sejarah hidupnya yaitu dipersatukan oleh Tuhan dalam pernikahan kudus. Kedua, membangkitkan kembali gairah cinta diantara pasangan suami istri yang mungkin sudah mulai luntur. Ketiga, sekaligus menjadi momen yang tepat bagi gereja untuk bisa memberikan pelayanan konseling kepada pasangan

591 Petrus 5:1-4

601 Timotius 3:1-13 
suami istri dengan tujuan untuk menguatkan, mengevaluasi dan mengintrospeksi hubungan suami istri selama menjalani kehidupan berumah tangga. Sebab acara spontanitas tersebut menjadi stimulan bagi pasangan suami istri untuk berinisiatif melakukan konseling keluarga. Keempat, bagi pihak gereja acara tersebut menjadi salah satu cara untuk membina setiap keluarga jemaat menjadi keluarga Kristen yang harmonis, yang senantiasa mempertahankan hubungan dan meningkatkan gairah cinta diantara mereka dalam pernikahan kudus.

\section{DAFTAR PUSTAKA}

2000 Alkitab Terjemahan Baru. Jakarta: Lembaga Alkitab Indonesia

Banks, Robert \& R. Paul Stevens

2012 The Complete Book of Everyday Christianity. Bandung: Kalam Hidup

Christenson, Larry

1994 Keluarga Kristen. Malang: Yayasan Persekutuan Betania

Crabb, Larry

1999 Konseling yang Efektif dan Alkitabiah. Yogyakarta: Yayasan Andi

Daugherty, Billy Joe

2001 Pernikahan Yang Kokoh. Jakarta: Metanoia

Gintings, E. P.

2009 Konseling Pastoral. Bandung: Jurnal Info Media

Hadisubrata, M. S

2008 Keluarga dalam Dunia Modern. Jakarta: BPK Gunung Mulia

Heruyono, Ki Bagus

2009 Landasan Teologis dan Seni Pelayanan Konseling. Blitar: diktat SOPGTI

Heruyono, Ki Bagus

2011 Pernikahan Awal Perjalanan Panjang. Blitar: Tiberias Blitar Publishing

Klemer, R. H

1965 Counseling in Marital and Sexual Problems: A Physician's Handbook. Baltimore: The Willams \& Wilkins Co 
Kusnadi, Djohan

2005 Pernikahan Yang Menuju Keharmonisan Optimal. Jakarta: PANCA JAYA

Latipun

2001 Psikologi Konseling. Malang: Universitas Muhammadiyah Malang

Mac Mahan, Oliver

2002 Gembala Jemaat Yang Sukses. Jakarta: Sinode GBI

Meier, Paul D. dkk,

2004 Pengantar Psikologi dan Konseling Kristen 2. Yogyakarta: ANDI

Oswari,

1982 Keluarga Idaman. Jambi: BPK GUNUNG MULIA

Soesilo, Vivian. A.

2001 Bimbingan Pranikah Cetakan Ke 3. Malang: SAAT

Surayin,

2001 Kamus Umum Bahasa Indonesia. Bandung: Yrama Widya

Susabda, Yakub B.

2007 Pelayanan Konseling Melalui Telepon. Yogyakarta: ANDI

Wijanarko, Jarot

2012 Hidup Produktif. Yogyakarta: ANDI

\section{Sumber Internet:}

Aliceginting.blogspot.com/2010/08/konseling-pastoral-terhadap-anakkorban.html?m=1

Id.m.wikipedia.org/wiki/konseling

www.mylifespring.com/artikel/konseling_kristen_dan_konseling_sekuler.php 